\title{
Availability to lactating dairy cows of methionine added to soy lecithins and mixed with a mechanically extracted soybean meal
}

\author{
D. W. Brake, ${ }^{*}$ E. C. Titgemeyer, ${ }^{* 1}$ M. J. Brouk, ${ }^{*}$ C. A. Macgregor, † J. F. Smith, ${ }^{*}$ and B. J. Bradford ${ }^{*}$ \\ ${ }^{*}$ Department of Animal Sciences and Industry, Kansas State University, Manhattan 66506 \\ †Grain States Soya, West Point, NE 68788
}

\begin{abstract}
We evaluated a product containing methionine mixed with soy lecithins and added to a mechanically extracted soybean meal (meSBM-Met). Lactational responses of cows, plasma methionine concentrations, and in vitro degradation of methionine were measured. Twenty-five Holstein cows were used in a replicated 5 $\times 5$ Latin square design and fed a diet designed to be deficient in methionine or the same diet supplemented either with 4.2 or $8.3 \mathrm{~g} / \mathrm{d}$ of supplemental methionine from a ruminally protected source or with 2.7 or 5.3 $\mathrm{g} / \mathrm{d}$ of supplemental methionine from meSBM-Met. All diets were formulated to provide adequate amounts of metabolizable lysine. Concentration of milk true protein was greater when methionine was provided by the ruminally protected methionine than by meSBM-Met, but milk protein yield was not affected by treatment. Milk yields and concentrations and yields of fat, lactose, solids-not-fat, and milk urea nitrogen were not affected by supplemental methionine. Body condition scores increased linearly when methionine from meSBM-Met was supplemented, but responses were quadratic when methionine was provided from a ruminally protected source. Nitrogen retention was not affected by supplemental methionine. Plasma methionine increased linearly when methionine was supplemented from a ruminally protected source, but plasma methionine concentrations did not differ from the control when supplemental methionine from meSBM-Met was provided. In vitro degradation of supplemental methionine from meSBM-Met was complete within $3 \mathrm{~h}$. Data suggest that meSBM-Met provides negligible amounts of metabolizable methionine to dairy cows, and this is likely related to extensive ruminal destruction of methionine; however, cow body condition may be improved by ruminally available methionine provided by meSBM-Met.
\end{abstract}

Received July 31, 2012.

Accepted January 22, 2013

${ }^{1}$ Corresponding author: etitgeme@ksu.edu
Key words: amino acid, dairy cow, methionine, soybean meal

\section{INTRODUCTION}

Increasing the efficiency with which dairy cows use $\mathrm{N}$ for productive purposes is a primary goal of protein nutrition. Because optimum profiles of AA are assumed to exist in MP for each physiological state of dairy cows (NRC, 2001), modifying AA flows to the duodenum to more closely match the optimal AA profile for the combined functions of maintenance and lactation might increase lactation performance and efficiency of $\mathrm{N}$ use in cows (Clark, 1975; Schwab et al., 1976; NRC, 2001). Although the AA content of microbial CP is well suited to support lactation (Schwab et al., 1976; Santos et al., 1998), the AA profiles of RUP may be less than ideal and could limit production.

When $\mathrm{N}$ is provided in amounts adequate to optimize ruminal fermentation, dietary additions of RUP often increase lactational performance (Titgemeyer and Shirley, 1997; Santos et al., 1998; NRC, 2001), and the preponderance of this response is assumed to be related to greater supplies of absorbed limiting AA (Clark, 1975; Schwab et al., 1976; NRC, 2001). Among commonly fed protein supplements, soybean meal and fish meal appear to have the best AA profile to support optimal efficiency of N utilization for lactation (Santos et al., 1998), but soy proteins are extensively degraded in the rumen and must be modified (e.g., chemically treated or heated) to increase RUP. Ruminal escape of soy protein increases when soybean meal is created by mechanical extrusion with soy lecithins (the fraction obtained by degumming the crude oil) added to the meal (Stern et al., 2005). The efficiency with which RUP from soybean meal is used is limited because the AA profile of soy proteins is usually not fully complementary with the AA provided by other sources of MP. Therefore, augmenting the absorbable AA profile of soybean meal with complementary limiting AA could improve efficiency of $\mathrm{N}$ use (Chen et al., 2011).

In lactating cows consuming diets based on corn and alfalfa, milk protein production and the efficiency of di- 
etary $\mathrm{N}$ use are often limited by absorbable amounts of Met and Lys (Schwab et al., 1976, 1992a; NRC, 2001). Production of milk protein may be increased by ruminally protected Met when Lys is not limiting (Vyas and Erdman, 2009; Patton, 2010). Vyas and Erdman (2009) suggested that milk protein yield can be increased (up to $16 \mathrm{~g}$ of milk protein/g of metabolizable Met intake) by additions of ruminally protected Met when Met is limiting. As a consequence of increases in milk protein content and yield in response to Met supplementation, technologies designed to prevent ruminal degradation of Met have garnered significant attention (NRC, 2001; Patton, 2010).

Macgregor et al. (2011) provided evidence from in situ fermentations that Met and Lys were resistant to ruminal degradation when added to a mechanically extracted soybean meal product. We hypothesized that Met in close association with soy lecithins may survive ruminal degradation and conducted 2 experiments to evaluate the ruminal degradation of Met mixed with soy lecithins and applied to mechanically extracted soybean meal.

\section{MATERIALS AND METHODS}

\section{Experiment 1: Lactation Responses in Cows}

Twenty-five multiparous (mean parity 2.3 , SD = 0.45) Holstein cows averaging (mean \pm SD) $44.9 \pm 7.0$ $\mathrm{kg}$ of milk/d, $87 \pm 28 \mathrm{DIM}$, and $630 \pm 54 \mathrm{~kg}$ of BW were blocked on DIM and placed in 1 of 5 replicates of $5 \times 5$ Latin squares. Effects of carryover from previous treatments were balanced across the experiment as well as possible. Experimental periods were $14 \mathrm{~d}$ and included an adequate amount of time for adaptation to treatments (10 d; Benefield et al., 2009), with samples collected in the final $4 \mathrm{~d}$ of each period. Cows were housed in tiestalls with free access to water, milked 3 times daily $(0200,1000$, and $1800 \mathrm{~h}$ ), and fed twice daily (0700 and $1900 \mathrm{~h}$ ) for ad libitum intake through individual mangers located in front of each stall. Total daily feed offerings were adjusted based on previous 24 -h intake so refusals were approximately $3 \%$. All sampling and animal husbandry protocols were approved by the Kansas State University Institutional Animal Care and Use Committee (Manhattan).

Treatments consisted of 5 separate diets (Table 1) fed as TMR, composed from a common basal mix that consisted primarily of corn silage, alfalfa hay, sorghum grain, and soybean hulls. Each diet was mixed by hand-blending additions to the basal mix of either mechanically extracted soybean meal with soy lecithins (meSBM; Soy Best, West Point, NE), meSBM plus either 2.5 or $5 \mathrm{~g}$ of metabolizable Met/d added as ru- men-protected DL-Met (RPMet; MetiPEARL; Kemin Industries Inc., Des Moines, IA; this product contained $55 \%$ DL-Met and was assumed to contain 33\% metabolizable Met), or 50 or $100 \%$ replacement of meSBM with meSBM with DL-Met added during manufacture (meSBM-Met; manufactured to contain $0.33 \%$ added Met, as-is basis), which was intended to deliver either 3.8 or $7.6 \mathrm{~g}$ of total Met/d when cows consumed 25.4 $\mathrm{kg}$ of diet DM. The meSBM-Met was manufactured using equipment that applied $8.15 \mathrm{~kg}$ of dry, crystalline DL-Met (99\% Met) per hour to a continuous stream of soybean cake (soybean remnants after lipid extraction, consisting largely of particles between $7.6 \times 12.7 \times$ $0.6 \mathrm{~cm}$ and $12.7 \times 35.6 \times 0.6 \mathrm{~cm}$ in size; Macgregor et al., 2005) in a mixing auger that produced 2,449 $\mathrm{kg}$ of treated soybean cake per hour; the product was ground in a hammer mill and cooled to ambient temperature. Attempts were made to provide similar levels of metabolizable Met from both meSBM-Met and RPMet; however, because the content of metabolizable Met from meSBM-Met was unknown, inclusions of Met were designed a priori based on the assumption that two-thirds of the DL-Met added to meSBM was resistant to ruminal degradation. Measured content of supplemental (free) Met in meSBM-Met was $0.23 \%$ (DM basis), which was less than that intended during manufacture. No free methionine was detected in meSBM. Based on these analyses, cows fed the diets containing meSBM-Met consumed 2.7 and $5.3 \mathrm{~g}$ of supplemental Met/d. If two-thirds of the added Met in meSBM-Met was protected from ruminal degradation (the basis for our treatment structure), the meSBMMet treatments would have provided 1.8 and $3.5 \mathrm{~g}$ of metabolizable Met/d.

Samples of the basal mix, meSBM, and meSBMMet $(200 \mathrm{~g} / \mathrm{d})$ corresponding to feed offerings on d 11 through 14 of each period were pooled and frozen $\left(-20^{\circ} \mathrm{C}\right)$ before analyses. Daily intake was calculated from feed offered and refused on d 11 through 14; $10 \%$ of refusals were retained daily, composited within period, and immediately frozen $\left(-20^{\circ} \mathrm{C}\right)$. Total milk yields were recorded, and a $25-\mathrm{mL}$ volume was collected at each milking during the final $4 \mathrm{~d}$ of each period. Milk samples were preserved with $8 \mathrm{mg}$ of bronopol and 0.3 mg of natamycin (D \& F Control Systems, Norwood, $\mathrm{MA}$ ), stored at $4^{\circ} \mathrm{C}$ after collection, and analyzed for fat, true protein, lactose, MUN, SNF, and somatic cells within $24 \mathrm{~h}$. To estimate $\mathrm{N}$ balance, urine and fecal samples were collected twice daily on d 11 through 14 of each period. Samples, which were pooled within cow by period, were collected at 1100 and $1500 \mathrm{~h}$ on $\mathrm{d} 11$, at 1000 and $1400 \mathrm{~h}$ on d 12 , at 1200 and $1600 \mathrm{~h}$ on d 13, and at 1300 and $1700 \mathrm{~h}$ on d 14. Immediately after each collection, $25 \mathrm{~mL}$ of urine was acidified $(\mathrm{pH}<3)$ with 
Table 1. Composition of diets fed to cows (\% of DM)

\begin{tabular}{|c|c|c|c|c|c|}
\hline \multirow[b]{3}{*}{ Item } & \multicolumn{5}{|c|}{ Dietary treatment } \\
\hline & \multirow[b]{2}{*}{ Control } & \multicolumn{2}{|c|}{ meSBM-Met $^{1}$} & \multicolumn{2}{|c|}{$\mathrm{RPMet}^{2}$} \\
\hline & & Low & High & Low & High \\
\hline \multicolumn{6}{|l|}{ Ingredient } \\
\hline Dry-rolled sorghum grain & 35.3 & 35.3 & 35.3 & 35.3 & 35.3 \\
\hline Corn silage & 25.2 & 25.2 & 25.2 & 25.2 & 25.2 \\
\hline Alfalfa & 15.2 & 15.2 & 15.2 & 15.2 & 15.2 \\
\hline Soybean hulls & 10.0 & 10.0 & 10.0 & 10.0 & 10.0 \\
\hline $\mathrm{meSBM}^{3}$ & 9.0 & 4.5 & - & 9.0 & 9.0 \\
\hline meSBM-Met ${ }^{4}$ & - & 4.5 & 9.0 & - & - \\
\hline MegaLac- $\mathrm{R}^{5}$ & 2.0 & 2.0 & 2.0 & 2.0 & 2.0 \\
\hline Calcium carbonate & 1.2 & 1.2 & 1.2 & 1.2 & 1.2 \\
\hline Sodium bicarbonate & 0.8 & 0.8 & 0.8 & 0.8 & 0.8 \\
\hline Monocalcium phosphate & 0.4 & 0.4 & 0.4 & 0.4 & 0.4 \\
\hline LysiPEARL ${ }^{6}$ & 0.3 & 0.3 & 0.3 & 0.3 & 0.3 \\
\hline Trace mineral salt ${ }^{7}$ & 0.3 & 0.3 & 0.3 & $\begin{array}{l}0.0 \\
0.3\end{array}$ & $\begin{array}{l}0.5 \\
0.3\end{array}$ \\
\hline Magnesium oxide & 0.2 & 0.2 & 0.2 & 0.2 & 0.2 \\
\hline Zinpro 4-plex ${ }^{8}$ & 0.05 & 0.05 & 0.05 & 0.05 & 0.05 \\
\hline Vitamin and mineral premix ${ }^{9}$ & 0.05 & 0.05 & 0.05 & 0.05 & 0.05 \\
\hline \multicolumn{6}{|l|}{ Chemical composition $^{10}$} \\
\hline $\mathrm{DM}$ & 60.8 & 60.8 & 60.7 & 60.8 & 60.8 \\
\hline $\mathrm{CP}(\%$ of $\mathrm{DM})$ & 14.3 & 14.3 & 14.3 & 14.3 & 14.3 \\
\hline $\mathrm{ADF}(\%$ of $\mathrm{DM})$ & 21.6 & 21.6 & 21.5 & 21.6 & 21.6 \\
\hline NDF ( $\%$ of DM) & 29.5 & 29.6 & 29.7 & 29.5 & 29.5 \\
\hline Crude fat ( $\%$ of $\mathrm{DM})$ & 3.8 & 3.8 & 3.8 & 4.0 & 4.0 \\
\hline Metabolizable $\mathrm{Met}^{11}$ (\% of MP) & 1.74 & - & - & 1.81 & 1.90 \\
\hline Metabolizable Lys ${ }^{11}$ ( $\%$ of MP) & 6.35 & - & - & 6.34 & 6.33 \\
\hline
\end{tabular}

${ }^{1}$ Mechanically extracted soybean meal with Met added during manufacture. Based on manufacturing process, low $=3.8 \mathrm{~g}$ of total Met/d and high $=7.6 \mathrm{~g}$ of total Met/d. Based on analysis of product, low $=2.7 \mathrm{~g}$ of total Met/d and high $=5.3 \mathrm{~g}$ of total Met/d.

${ }^{2}$ Ruminally protected Met (RPMet) as MetiPEARL (Kemin Industries Inc., Des Moines, IA; product assumed to contain $33 \%$ metabolizable Met). Low $=2.5 \mathrm{~g}$ of metabolizable Met $/ \mathrm{d}$; high $=5.0 \mathrm{~g}$ of metabolizable Met $/ \mathrm{d}$. ${ }^{3}$ Mechanically extracted soybean meal with soy lecithins added during manufacture. Contained by analysis $(\%$ of DM) Asp, 5.05; Thr, 1.71; Ser, 2.37; Glu, 8.02; Gly, 1.89; Ala, 1.94; Val, 1.97; Ile, 2.23; Leu, 3.41; Tyr, 1.38; Phe, 2.25; His, 1.15; Lys, 2.59; Arg, 2.73; Cys, 0.62; Met, 0.52; and free Met, none detected.

${ }^{4}$ Mechanically extracted soybean meal with Met mixed with soy lecithins and added during manufacture. Contained by analysis (\% of DM) Asp, 4.95; Thr, 1.70; Ser, 2.32; Glu, 7.88; Gly, 1.87; Ala, 1.92; Val, 1.97; Ile, 2.22; Leu, 3.38; Tyr, 1.29; Phe, 2.24; His, 1.12; Lys, 2.47; Arg, 2.67; Cys, 0.59; Met, 0.69; and free Met, 0.23.

${ }^{5}$ Calcium soaps of long-chain FA (Church and Dwight Co., Princeton, NJ).

${ }^{6}$ Ruminally protected Lys provided $16.2 \mathrm{~g} / \mathrm{d}$ of metabolizable Lys (Kemin Industries Inc.; product assumed to contain $21 \%$ metabolizable Lys).

${ }^{7}$ Contained $96 \% \mathrm{NaCl}, 0.35 \% \mathrm{Zn}, 0.2 \% \mathrm{Fe}, 0.2 \% \mathrm{Mn}, 0.03 \% \mathrm{Cu}, 0.007 \% \mathrm{I}$, and $0.005 \% \mathrm{Co}$.

${ }^{8}$ Contained $2.58 \%$ Zn as Zn-Met; $1.43 \%$ Mn as Mn-Met; 0.90\% Cu as Cu-Lys; 0.18\% Co as Co-glucoheptonate (Zinpro Corp., Eden Prairie, MN).

${ }^{9}$ Provided to diets (DM basis) 3,300 IU of vitamin A/kg, 2,250 IU of vitamin D/kg, 35 IU of vitamin E/ $\mathrm{kg}$, and $0.06 \mathrm{mg}$ of $\mathrm{Se} / \mathrm{kg}$.

${ }^{10}$ Calculated based on analyses of samples of the basal mix, meSBM, and meSBM-Met.

${ }^{11}$ Estimated from the NRC (2001) model. Values for diets containing meSBM-Met were not calculated because ruminal escape and intestinal digestion of escaped Met were unknown.

an addition of $9 \mathrm{~mL}$ of $1 \mathrm{M} \mathrm{H}_{2} \mathrm{SO}_{4}$ and frozen $\left(-20^{\circ} \mathrm{C}\right)$ until analysis. If cows did not defecate during urine collections, they were stimulated to do so via rectal palpation, and approximately $225 \mathrm{~g}$ of feces was retained at each sampling time and pooled. Whole blood was harvested from the coccygeal vein into 10-mL heparinized blood collection tubes (Becton, Dickinson and Co., Franklin Lakes, NJ) at $1400 \mathrm{~h}$ on d 14 of each period. Immediately after collection, blood tubes were placed on ice and transported to the laboratory where plasma was separated via centrifugation $\left(1,200 \times g\right.$ at $4^{\circ} \mathrm{C}$ for $15 \mathrm{~min}$ ); plasma was subsequently frozen for later analysis of AA. Cow BW was measured at the beginning of the trial and after the final milking of each period, and BCS was determined by one trained technician at the end of each period (Wildman et al., 1982).

Feed components, orts, and feces were thawed at room temperature $\left(22^{\circ} \mathrm{C}\right)$ and subsequently dried $\left(55^{\circ} \mathrm{C}\right)$ in a 
forced-air oven for $72 \mathrm{~h}$ before being ground to pass a 1-mm screen (Thomas-Wiley laboratory mill model 4; Thomas Scientific USA, Swedesboro, NJ) before analyses of DM, NDF, ADF, and acid detergent insoluble ash (ADIA). Dry matter content was determined by drying samples at $105^{\circ} \mathrm{C}$ for $24 \mathrm{~h}$ in a forced-air oven. The wet chemistry techniques of Van Soest et al. (1991) were used to quantify NDF (with $\alpha$-amylase and sodium sulfite), ADF (nonsequential), and ADIA. Feed components were analyzed for crude fat (method number 2003.06; AOAC International, 2006). Nitrogen content of feed components, orts, wet feces, and urine were determined through combustion (nitrogen analyzer model FP-2000; Leco Corp., St. Joseph, MI), and $\mathrm{CP}$ was calculated as $6.25 \times \mathrm{N}$. Urine creatinine was measured (Chasson et al., 1961) with an Technicon AutoAnalyzer II (Technicon Industrial Systems, Buffalo Grove, IL), and urine output was estimated assuming that creatinine was excreted at a rate of $29 \mathrm{mg} /$ $\mathrm{kg}$ of BW (Valadares et al., 1999). Fecal DM output was estimated as ADIA consumption divided by ADIA concentration in feces (Merchen, 1988). Secretion of N in milk was calculated as milk true protein divided by 6.38 .

Milk samples were analyzed by Heart of America DHIA (Manhattan, KS). Concentrations of milk fat, true protein, and lactose were determined via infrared absorbancies (B-2000 infrared analyzer; Bentley Instruments Inc., Chaska, MN). Milk urea $\mathrm{N}$ was quantified colorimetrically (MUN spectrophotometer, Bentley Instruments Inc.), and somatic cells were counted using dual laser flow cytometry (Somacount 500; Bentley Instruments Inc.). Energy-corrected milk was calculated as follows: $(7.2 \times \mathrm{kg}$ of protein $/ \mathrm{d})+(12.95 \times \mathrm{kg}$ of fat $/ \mathrm{d})+(0.327 \times \mathrm{kg}$ of milk/d) (Tice et al., 1993).

Plasma free AA were determined by HPLC after deproteinization with sulfosalicylic acid $(5 \%$ wt/vol; Campbell et al., 1997). Chromatography was achieved on a Li cation-exchange column $(4.0 \times 100 \mathrm{~mm}$; Pickering Laboratories Inc., Mountain View, CA) at a continuous flow rate of $0.3 \mathrm{~mL} / \mathrm{min}$ after passing a $\mathrm{Li}$ guard column $(2.0 \times 20 \mathrm{~mm}$; Pickering Laboratories Inc. $)$. The initial mobile phase (32 min) was $\mathrm{pH} 2.75$, then a mobile phase at $\mathrm{pH} 3.37$ was pumped for $18 \mathrm{~min}$, and a final eluent ( $\mathrm{pH}$ 7.50) was used for $33 \mathrm{~min}$. Between samples, the column was regenerated by pumping $\mathrm{LiOH}(0.4 \%$ $\mathrm{wt} / \mathrm{vol}$ ) for $7 \mathrm{~min}$, and then reequilibrated to the first carrier solution for $45 \mathrm{~min}$. Column temperature was initially maintained at $38^{\circ} \mathrm{C}(50 \mathrm{~min})$ and then heated to $63^{\circ} \mathrm{C}$ for $35 \mathrm{~min}$ before being cooled at a constant rate over $50 \mathrm{~min}$ to reach $38^{\circ} \mathrm{C}$. After elution from the column, AA were derivatized with $o$-phthalaldehyde in a short coil at $50^{\circ} \mathrm{C}$ before fluorescence was measured (excitation at $330 \mathrm{~nm}$ and emission at $465 \mathrm{~nm}$ ), and AA were quantified with reference to an internal standard (100 $\mathrm{m} M$ norleucine).

Concentrations of AA in meSBM and meSBM-Met were measured as described for plasma free AA following acid hydrolysis (with $6 \mathrm{M} \mathrm{HCl}$ for $24 \mathrm{~h}$ at $105^{\circ} \mathrm{C}$ ). Total Met and Cys were measured as methionine sulfone and cysteic acid in samples hydrolyzed after performic acid oxidation (Moore, 1963). The amount of Met added to meSBM-Met (free Met) was quantified by HPLC after extraction to ensure release of methionine from the lipid matrix in which it was added to the product. Extraction of lipid-associated Met was achieved by vortexing samples (100 to $200 \mathrm{mg}$ ) after addition of 15 $\mathrm{mL}$ of a hexane:isopropanol solution $(3: 2 \mathrm{vol} / \mathrm{vol})$. Subsequently, $25 \mathrm{~mL}$ of water containing $1 \mathrm{mM}$ norleucine was mixed with samples before centrifugation $(1,500$ $\times g$ for $15 \mathrm{~min}$ ) and removal of the hexane layer. An aliquot $(750 \mu \mathrm{L})$ of the remnant aqueous layer was then mixed (1:1 vol $/ \mathrm{vol})$ with $1 \%$ (wt/vol) perchloric acid (UriPrep; Pickering Laboratories Inc.) and chilled on ice for $30 \mathrm{~min}$ before centrifugation $(17,000 \times g$ for 10 min). The resultant supernatant was then analyzed for Met content as described for plasma free AA.

Of 125 possible observations, 122 were collected. One cow became ill (traumatic reticuloperitonitis), was treated, and returned to its typical levels of intake and production before sampling in the next period. As a result, data from this cow for the single period it was ill were excluded from analyses (treatment $=$ low level of RPMet). Another cow became ill (bovine leukosis) and demonstrated low DMI and milk production during the final 2 periods. All data collected from this cow during the final 2 periods were excluded from analyses (treatments = high level of RPMet and control).

\section{Statistical Analysis}

Data from each cow were analyzed for a Latin square using PROC MIXED of SAS (version 9.1; SAS Institute Inc., Cary, NC) with the following model:

$$
\mathrm{Y}_{\mathrm{ijk}}=\mu+\mathrm{D}_{\mathrm{i}}+\mathrm{P}_{\mathrm{j}}+\mathrm{C}_{\mathrm{k}}+\varepsilon_{\mathrm{ijk}},
$$

where $Y_{\mathrm{ijk}}=$ the dependent variable, $\mu=$ overall mean, $\mathrm{D}_{\mathrm{i}}=$ fixed effect of $\operatorname{diet}(\mathrm{i}=1, \ldots, 5), \mathrm{P}_{\mathrm{j}}=$ fixed effect of period $(\mathrm{j}=1, \ldots, 5), \mathrm{C}_{\mathrm{k}}=$ random effect of cow $(\mathrm{k}=1, \ldots, 25)$, and $\varepsilon_{\mathrm{ijk}}=$ residual error. When the $F$-statistic for diet was significant $(P \leq 0.05)$, linear and quadratic contrasts within each Met source (i.e., RPMet or meSBM-Met) were tested, as was a contrast comparing the mean of both levels of meSBM-Met against the mean of both levels of RPMet. Difference of the overall average of $\mathrm{N}$ retention from 0 was determined using Student's $t$-test. 


\section{Experiment 2: In Vitro Degradation of Added Met}

Fresh ruminal fluid $(1.5 \mathrm{~L})$ was collected from the ventral sac of 2 Holstein cows $(55 \pm 11$ DIM $)$ maintained on a ration containing $33 \%$ wet corn gluten meal, $21 \%$ corn silage, $19 \%$ alfalfa hay, $8 \%$ finely rolled corn, $6 \%$ whole cottonseed, $5 \%$ finely rolled milo, and $5 \%$ meSBM. Ruminal fluid was immediately strained through 4 layers of cheesecloth and then transported to the laboratory in a thermally insulated container. After an additional straining of ruminal contents through 4 layers of cheesecloth, aliquots $(10 \mathrm{~mL})$ of ruminal fluid were placed in duplicate $50-\mathrm{mL}$ screw-top glass tubes containing substrate and $20 \mathrm{~mL}$ of anaerobic McDougall's buffer (McDougall, 1948). Substrates (300 mg as is) included solvent-extracted soybean meal (a negative control), meSBM-Met, and meSBM with crystalline DL-Met added to tubes in an amount similar to that for meSBM-Met. Immediately following addition of ruminal fluid, tubes were gassed with $\mathrm{CO}_{2}$, capped with a rubber stopper equipped with a vent to allow release of gases, and incubated at $39^{\circ} \mathrm{C}$ for 0,3 , or $6 \mathrm{~h}$. Culture fermentations were stopped by adding $0.375 \mathrm{~mL}$ of $6 \mathrm{M}$ $\mathrm{HCl}$ (containing norleucine as an internal standard for AA analysis) to adjust $\mathrm{pH}$ to near 2 . Tubes were stored at $-20^{\circ} \mathrm{C}$ until lyophilization.

Total free Met content was analyzed after lipid removal. Triacylglycerols and FFA were dissolved by vortexing lyophilized cultures with $9 \mathrm{~mL}$ of hexane:methanol (1:2 $\mathrm{vol} / \mathrm{vol}$ ). Tubes were then placed in an ice bath until the hexane and methanol phases began to separate and then $3 \mathrm{~mL}$ of cold $\left(0^{\circ} \mathrm{C}\right)$ hexane was added, and tubes were centrifuged at $1,500 \times g$ for $10 \mathrm{~min}$. The hexane layer was removed, and $6 \mathrm{~mL}$ of cold hexane and $6 \mathrm{~mL}$ of $0.3 \%$ (wt/wt) $\mathrm{NaCl}$ were added and vortexed before centrifugation $(1,500 \times g$ for $10 \mathrm{~min})$ and removal of the hexane phase. Phospholipids in the aqueous phase were removed by adding $16.5 \mathrm{~mL}$ of chloroform:methanol $(2.5: 3 \mathrm{vol} / \mathrm{vol})$, followed by $10 \mathrm{~mL}$ of $0.3 \%$ (wt/wt) $\mathrm{NaCl}$. Following centrifugation, the chloroform layer was removed. To ensure recovery of methionine, $10 \mathrm{~mL}$ of $0.3 \%$ (wt/wt) $\mathrm{NaCl}$ was added to the chloroform layer, vortexed, and centrifuged $(1,500 \times g$ for $10 \mathrm{~min})$, and the aqueous layer was added to the previously collected aqueous phase. The combined aqueous phase was used for analysis of free Met. Samples were prepared for AA analysis by mixing a portion of the aqueous phases with an equal volume of $1 \%$ (wt/vol) perchloric acid (UriPrep; Pickering Laboratories Inc.), chilling on ice for $30 \mathrm{~min}$, and centrifuging at $17,000 \times g$ for 10 min. Free Met was determined by HPLC as described above. Free Met values were corrected within rumen fluid source and incubation time for free Met in the negative control.

\section{Statistical Analysis}

Percentages of free Met remaining were analyzed as a randomized complete block design with PROC MIXED of SAS using the following model:

$$
\mathrm{Y}_{\mathrm{ijk}}=\mu+\mathrm{C}_{\mathrm{i}}+\mathrm{S}_{\mathrm{j}}+\mathrm{T}_{\mathrm{k}}+\mathrm{ST}_{\mathrm{jk}}+\varepsilon_{\mathrm{ijk}},
$$

where $Y_{\mathrm{ijk}}=$ the dependent variable, $\mu=$ overall mean, $\mathrm{C}_{\mathrm{i}}=$ random effect of cow ( $\mathrm{i}=1$ or 2$), \mathrm{S}_{\mathrm{j}}=$ fixed effect of Met source ( $\mathrm{j}=1$ or 2$), \mathrm{T}_{\mathrm{k}}=$ fixed effect of fermentation time $(\mathrm{k}=1,2$, or 3$), \mathrm{ST}_{\mathrm{jk}}=$ fixed effect of the interaction of Met source and time of fermentation; and $\varepsilon_{\mathrm{ijk}}=$ residual error. When the $F$-statistic was significant $(P \leq 0.05)$, means were separated using Student's $t$-test with the PDIFF option of SAS. Means were evaluated for difference from 0 with a 2 -tailed Student's t-test.

\section{RESULTS}

\section{Experiment 1: Lactation Responses in Cows}

The chemical compositions of each diet were based on analyses of the basal mix, meSBM, and meSBMMet. Concentrations of DM, OM, CP, ADF, NDF, and crude fat were similar among diets (Table 1). As expected, DM (meSBM $=89.8 \%$, meSBM-Met $=$ $88.3 \%), \mathrm{OM}(\mathrm{meSBM}=93.4 \%$, meSBM-Met $=93.6 \%)$, $\mathrm{NDF}(\mathrm{meSBM}=16.9 \%$, meSBM-Met $=19.6 \%), \mathrm{ADF}$ $(\operatorname{meSBM}=14.4 \%$, meSBM-Met $=13.7 \%)$, and $\mathrm{CP}$ $($ meSBM $=45.1 \%$, meSBM-Met $=45.0 \%)$ were similar between soybean meals. Concentrations of metabolizable Met and Lys in MP were estimated for the control diet using the NRC (2001) model, which contained feed library information for all dietary ingredients. Metabolizable Met was $1.74 \%$ of MP for the control diet and was predicted to increase to $1.90 \%$ of MP for the diet supplemented with $5 \mathrm{~g} / \mathrm{d}$ of metabolizable Met from RPMet (Table 1). Metabolizable Lys averaged 6.34\% of MP across all diets. The control diet was designed to supply adequate amounts of metabolizable Lys but insufficient amounts of metabolizable Met to support optimal lactation performance, which was indicated by an estimated metabolizable Lys:Met ratio of 3.65 (NRC, 2001).

Overall, DMI averaged $25.4 \mathrm{~kg} / \mathrm{d}$ and was not affected by diet (Table 2). Apparent digestibilities of DM and N (62.9 and $61.3 \%$, respectively; Table 2) were not affected by treatment. Milk yield averaged $44.8 \mathrm{~kg} / \mathrm{d}$ and contained, on average, $2.81 \%$ milk fat and $8.6 \mathrm{mg}$ of MUN/dL. No differences were observed for milk yield, and the concentration and yields of fat, lactose, SNF, and MUN did not differ among diets (Table 2). 
Milk true protein concentration was greater $(P<0.01)$ when Met was supplemented as RPMet rather than as meSBM-Met. Despite dietary effects on concentration of milk true protein, milk protein yields did not differ among diets. Because DMI, milk yields, and milk energy component yields did not differ among treatments, the efficiency of ECM production did not differ.

No differences among diets were detected for BW gain $(P=0.90)$ and, on average, cows gained $7.0 \mathrm{~kg}$ per period (Table 2). In addition, $\mathrm{N}$ retention did not differ among diets $(P=0.30)$. The average $\mathrm{N}$ retention of $7 \mathrm{~g} / \mathrm{d}$ was greater than $0(P=0.04)$. Because dietary $\mathrm{CP}$ concentration was not different among diets, $\mathrm{N}$ intake $(588 \mathrm{~g} / \mathrm{d})$ did not differ among treatments, and this contributed to similar amounts of $\mathrm{N}$ excreted in urine and feces (Table 2). Additions of dietary Met from meSBM-Met linearly increased BCS, but when Met was increased via RPMet, BCS increased in a quadratic manner, with the lower level of Met resulting in a greater response than the higher level of Met.

Except for concentrations of Met and Ser, concentrations of plasma free AA were not affected by treatment (Table 3). Plasma Met increased linearly $(P=0.03)$ when greater amounts of supplemental Met were provided by RPMet, but not when Met was provided by meSBM-Met. Linear increases $(P=0.03)$ in plasma Ser also were observed when greater amounts of RPMet were included, but plasma Ser did not differ from the control when meSBM-Met was included in diets. Because concentrations of total AA in plasma increased numerically in response to RPMet (linear; $P=0.27$ ), we were concerned that increases in plasma Met might

Table 2. Effect of supplemental Met from mechanically extracted soybean meal with Met added during processing (meSBM-Met) or from ruminally protected Met (RPMet) on production, nitrogen status, and digestibility of lactating dairy cows

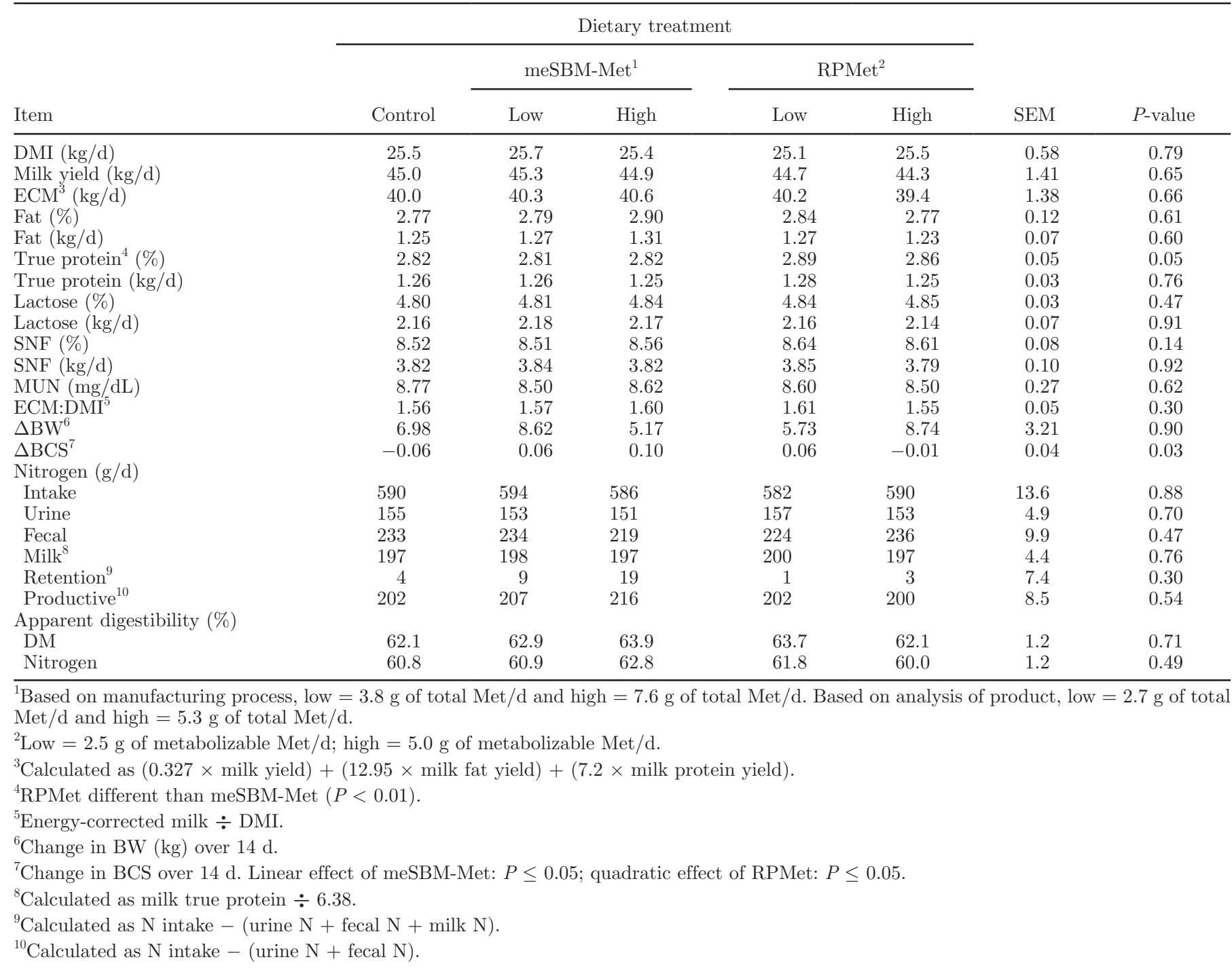


Table 3. Effect of supplemental Met from mechanically extracted soybean meal with Met added during processing (meSBM-Met) or from ruminally protected Met (RPMet) on plasma free AA concentrations of lactating dairy cows

\begin{tabular}{|c|c|c|c|c|c|c|c|}
\hline $\begin{array}{l}\text { AA } \\
(\mu M)\end{array}$ & \multicolumn{5}{|c|}{ Dietary treatment } & SEM & $P$-value \\
\hline Taurine & 56.1 & 49.8 & 51.9 & 55.1 & 53.2 & 2.5 & 0.16 \\
\hline Asp & 8.8 & 8.7 & 9.1 & 9.3 & 9.5 & 0.36 & 0.35 \\
\hline Thr & 104.0 & 101.6 & 99.7 & 105.6 & 105.4 & 3.9 & 0.58 \\
\hline Glu & 47.4 & 45.1 & 45.9 & 45.4 & 50.6 & 2.0 & 0.21 \\
\hline Gln & 226.3 & 221.8 & 232.2 & 231.2 & 228.9 & 7.4 & 0.61 \\
\hline Gly & 419.8 & 419.8 & 400.9 & 430.7 & 434.9 & 22.7 & 0.45 \\
\hline Ala & 263.0 & 267.3 & 251.9 & 271.4 & 272.9 & 11.2 & 0.40 \\
\hline Val & 283.1 & 282.0 & 281.4 & 289.7 & 286.9 & 13.8 & 0.97 \\
\hline $\mathrm{Met}^{3}$ & 28.9 & 28.7 & 29.0 & 30.6 & 31.0 & 0.77 & 0.04 \\
\hline Ile & 165.7 & 164.0 & 168.0 & 171.8 & 175.6 & 8.9 & 0.79 \\
\hline Lys & 75.8 & 76.1 & 76.1 & 79.6 & 81.3 & 3.4 & 0.51 \\
\hline Arg & 88.0 & 85.7 & 87.3 & 92.1 & 92.7 & 2.9 & 0.21 \\
\hline
\end{tabular}

${ }^{1}$ Based on manufacturing process, low $=3.8 \mathrm{~g}$ of total Met/d of total and high $=7.6 \mathrm{~g}$ of total Met/d. Based on analysis of product, low $=2.7$ $\mathrm{g}$ of total Met/d and high $=5.3 \mathrm{~g}$ of total Met/d.

${ }^{2}$ Low $=2.5 \mathrm{~g}$ of metabolizable Met $/ \mathrm{d}$; high $=5.0 \mathrm{~g}$ of metabolizable Met $/ \mathrm{d}$.

${ }^{3}$ RPMet and meSBM-Met differed $(P \leq 0.01)$. Linear effect of RPMet: $P \leq 0.05$.

be influenced similarly. When plasma Met concentrations were analyzed as a fraction of total AA, however, the same linear increases in response to RPMet were evident, although the significance of the effect (linear; $P=0.11)$ was less than when plasma Met concentrations were analyzed directly.

\section{Experiment 2: In Vitro Degradation of Added Met}

The proportions of nonpeptide-bound Met that were not degraded by ruminal microbes after 0,3 , or $6 \mathrm{~h}$ of incubation are displayed in Figure 1. The percentage of added Met that remained did not differ between crystalline Met added directly to in vitro tubes and Met added as a part of meSBM-Met. As expected, Met was rapidly degraded when it was added to in vitro tubes in a crystalline form, and the amount of Met remaining after $3 \mathrm{~h}$ of fermentation was not different from $0(P=$ 0.61 ). Similarly, proportions of supplemental Met from meSBM-Met that escaped degradation were not different from 0 after $3 \mathrm{~h}$ of incubation $(P=0.73)$, and this value was also not different $(P=0.96)$ from the proportion remaining from crystalline Met. Proportions of supplemental Met from either crystalline Met or from meSBM-Met that remained following $6 \mathrm{~h}$ of fermentation were similarly small and not different from $0(P$ $=0.37$ ).

\section{DISCUSSION}

A great deal of research in the past several decades has focused on elucidating the role of Met in the production of milk and milk constituents in lactating cows. Supplementing cows with greater amounts of metabolizable Met can increase their milk production (Yang et al., 1986; Casper et al., 1987; Schingoethe et al., 1988b). Some authors have reported increased concentrations of milk fat (Samuelson et al., 2001) and protein (Casper et al., 1987; Ordway et al., 2009; Weiss and St-Pierre, 2009) in response to supplementation of metabolizable Met, and others have indicated that yields of milk fat (Overton et al., 1996; Kröber et al., 2000; Davidson et al., 2008) and protein (Yang et al., 1986; Armentano et al., 1997; Davidson et al., 2008) were increased; however, other data demonstrated no improvements in milk yield (Overton et al., 1998; Blum et al., 1999; Broderick and Muck, 2009), percentage of milk fat and protein (Overton et al., 1998; Broderick et al., 2008; Broderick and Muck, 2009), or fat and protein yields (Bertrand et al., 1998; Broderick et al., 2008; Phipps et al., 2008) in response to supplementation of metabolizable Met. Several recent summaries of the data concerning Met supplementation to lactating cows (Vyas and Erdman, 2009; Patton, 2010) concluded that milk protein content is the production parameter that is most responsive to 


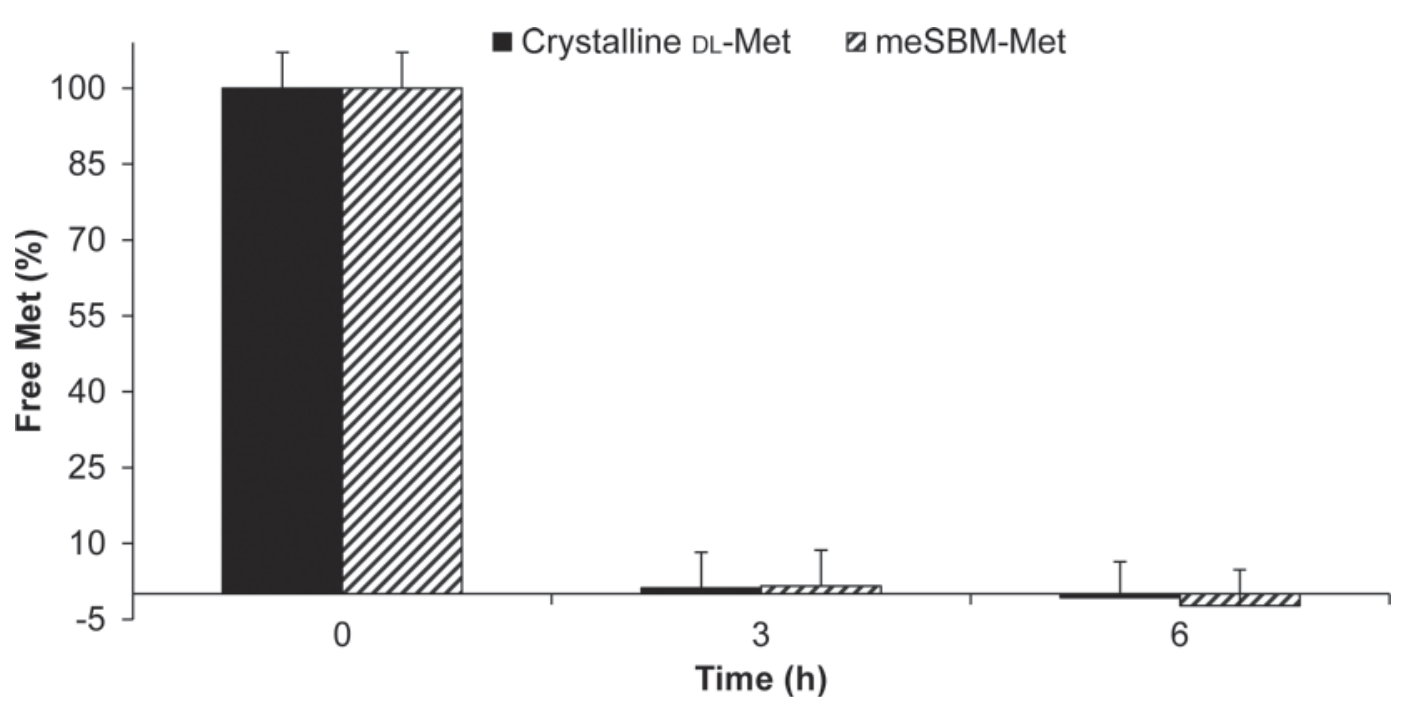

Figure 1. Percentage of free Met remaining from either mechanically extracted soybean meal with added crystalline DL-Met or mechanically extracted soybean meal with DL-Met mixed with soy lecithins and added during manufacture (meSBM-Met). No differences among treatments or interactions between treatment and time existed $(P \geq 0.95)$. Means at $0 \mathrm{~h}$ differ from those at 3 or $6 \mathrm{~h}(P<0.01)$. Treatment means at 3 or $6 \mathrm{~h}$ did not differ from $0(P \geq 0.61)$.

metabolizable Met supply. Metabolizable Met generally increased milk protein yield, but this increase was typically associated with improvements in milk yields, which occurred less often than increases in concentration of milk protein (Patton, 2010).

In our study, the only lactational response affected by supplemental Met was the percentage of milk true protein. The RPMet was intended to serve as a positive control, and only diets with RPMet demonstrated the response in true protein content. Increases in the percentage of milk true protein without improvements in milk yield or milk protein yield in response to supplemental Met are in agreement with the conclusions of Patton (2010). Furthermore, the lactation responses that we observed to RPMet were similar to the report of Schingoethe et al. (1988b), in which they provided ruminally protected Met to cows fed diets containing an extruded blend of soybeans and soybean meal.

Schwab et al. (1992b) suggested that milk yields of cows in peak, but not early, mid, or late lactation, are responsive to the supply of metabolizable Met and Lys. Schwab et al. (1992a) observed increases in milk yields in mid-lactation cows when Lys and Met were supplemented, but not in peak, early, or late lactation. Cows in our study were intermediate between the peak lactation (4 to $8 \mathrm{wk}$ postpartum) and early lactation (14 to 20 wk postpartum) cows of Schwab et al. (1992b). Milk yields and, thus, milk constituent yields, may not have been responsive to Met from RPMet in our study because cows were too advanced in lactation to respond with changes in milk protein secretion. Because milk protein may not be responsive to Met supplementation at all stages of lactation, we included measures of $\mathrm{N}$ retention, which might be responsive to Met in situations where milk protein is not.

Another possible explanation for the lack of a lactation response to supplemental Met is that significant amounts of phosphatidylcholine provided to cows from meSBM or meSBM-Met reduced requirements for Met below basal amounts provided by the diets, although choline is unable to replace Met requirements for growing cattle (Löest et al., 2002). Phosphatidylcholine, which can be rapidly metabolized to choline postruminally (Pinotti et al., 2002), represents a significant portion of soy lecithins ( $20 \%$; Scholfield, 1981), which accounted for $5 \%$ of the wet weight of meSBM (Macgregor et al., 2005). Supplementation of absorbable choline may increase secretion of milk (Sharma and Erdman, 1988, 1989; Erdman and Sharma, 1991). Although nonesterified choline and choline in phosphatidylcholine are rapidly and extensively degraded in the rumen (Neill et al., 1978, 1979; Dawson et al., 1981), some evidence indicates that a portion of soy lecithins escape ruminal degradation (Jenkins et al., 1989; Shain et al., 1993; Abel-Caines et al., 1998).

A more likely explanation for the lack of a lactation response to supplemental Met is that another AA limited the response to Met. All diets were designed to contain moderate amounts of CP $(14.3 \%)$ and adequate metabolizable Lys (relative to metabolizable Met). This was done to exacerbate deficiencies in absorbable Met and allow for greater responses to supplemental Met (Vyas and Erdman, 2009). Schwab et al. (1976) reported that AA other than Met and Lys can limit lac- 
tation performance. When Fraser (1988) summarized the available reports (Yang et al., 1986; Casper et al., 1987; Illg et al., 1987) of the ratio of AA extracted from the blood plasma by mammary tissue to AA secreted in milk in lactating cows fed diets containing extruded, heated, or raw soybean meal, she concluded that His was the most limiting AA for production when supplements of metabolizable Met were provided. In addition, Doepel et al. (2004) reported that content of His in MP limited milk protein yields to an extent similar to Met, and that responses in milk protein yields were most sensitive to increases in absorbable His. The efficiency with which cattle utilize AA for productive purposes is undoubtedly dynamic (Doepel et al., 2004; Schroeder et al., 2006), and levels of dietary N supply may affect the order in which AA limit production (Fraser, 1988; Phipps et al., 2008).

Across all diets, milk fat percentage was low $(2.8 \%)$ compared with current industry standards (3.6\%; NASS, 2011) as well as all multiparous cows in the Kansas State University herd at the time this trial was conducted $(3.4 \%)$. Depressions in milk fat percentage typically occur when greater amounts of biohydrogenation intermediates (i.e., trans-dienes) of vegetable fat (particularly trans-10,cis-12 conjugated linoleic acid) are absorbed by lactating cows (Bauman and Griinari, 2003; Jenkins and McGuire, 2006; Shingfield et al., 2006). Fat in all diets consisted primarily of vegetable fat from meSBM and calcium soaps of long-chain FA, but the overall concentration of crude fat (3.9\% of DM) was modest. Milk fat concentrations could have been reduced by absorption of biohydrogenation intermediates from either meSBM (Schingoethe et al., 1988b; Jenkins et al., 1989; Firkins et al., 2008) or calcium soaps of FA (Chikunya et al., 2004; Block et al., 2008; Côrtes et al., 2010). Regardless of the cause, it is unlikely that the observed milk fat depression diminished lactational responses to supplemental Met. Net energy balance is often more positive when biohydrogenation intermediates depress milk fat in early lactation cows (Moore et al., 2004). Furthermore, Patton (2010) showed that when Met was supplemented, cows with a more positive energy balance typically had a greater response in milk yield, but that responses in milk protein were not affected when cows consumed excess amounts of energy.

During early lactation, cows are unable to consume adequate amounts of nutrients to account for nutrients secreted in milk (Schingoethe et al., 1988a). Thus, cows in early lactation typically mobilize body tissue to support lactation, and may thereby conceal responses to Met on lactation performance because milk protein is maintained at the expense of body protein stores (Paquay et al., 1972; Broderick et al., 2008). We measured $\mathrm{N}$ balance with this concern in mind and found no differences among diets for $\mathrm{N}$ balance, suggesting that tissue deposition was not affected by the supplemental Met. Amounts of $\mathrm{N}$ retained (overall average was $7.2 \mathrm{~g}$ of $\mathrm{N} / \mathrm{d}$ ) were small, but greater than 0 , indicating that cows were not mobilizing significant amounts of body tissue to support lactation.

Increases in BCS when supplemental Met was provided as meSBM-Met might be explained by ruminally available Met stimulating microbial growth and improving efficiency of feed energy use (Patterson and Kung, 1988; Russell and Strobel, 1993; Wallace, 1994; St-Pierre and Sylvester, 2005). Because Met in meSBM-Met was rapidly degraded by ruminal microflora in vitro, ruminally available Met may have improved energetic efficiencies of fermentation and contributed to linear increases in cow BCS.

Linear increases in plasma free Met concentrations when RPMet, but not meSBM-Met, was the source of supplemental Met support the conclusion that metabolizable Met levels were increased by RPMet but not by meSBM-Met. Increases in plasma Met concentrations may be related to increased absorption of D-Met from the intestine (Met was provided as a racemic mixture). Cattle are clearly able to utilize D- and L-Met for productive purposes with similar efficiency, but D-Met supplementation leads to greater plasma Met concentrations, presumably because of a slower rate of metabolism of D-Met compared with L-Met (Campbell et al., 1996; Lapierre et al., 2012). This hypothesis would explain increased concentrations of plasma Met from RPMet. Regardless of the cause for elevated concentrations of plasma Met, increased amounts of metabolizable Met clearly were provided by RPMet. Concentrations of plasma Met were not affected by supplemental Met from meSBM-Met, and in vitro fermentation indicated a rapid destruction of supplemental Met in meSBMMet; in total, these data indicate that only negligible amounts of supplemental Met from meSBM-Met contributed to the metabolizable Met supply.

\section{CONCLUSIONS}

Supplemental Met provided by RPMet increased milk content of true protein but had no effect on true protein yield. Supplemental Met provided by RPMet increased plasma free Met concentrations. Neither milk protein content nor plasma Met were changed by supplemental Met provided by the meSBM-Met. Subsequent in vitro fermentations of meSBM-Met indicated that added Met was rapidly destroyed by ruminal microflora. Under the conditions of this experiment, only negligible amounts of Met from meSBM-Met seemed to escape ruminal destruction and contribute to the metabolizable Met supply of lactating cows. Nonetheless, 
BCS was improved by ruminally available methionine provided by meSBM-Met.

\section{ACKNOWLEDGMENTS}

This article is contribution no. 12-461-J from the Kansas Agricultural Experiment Station, Manhattan. We acknowledge the financial support provided by Grain States Soya (West Point, NE). We also thank Cheryl Armendariz (Kansas State University, Manhattan) for her assistance in sample analyses and Jaymelynn Farney (Kansas State University, Manhattan) for her assistance in evaluation of BCS.

\section{REFERENCES}

Abel-Caines, S. F., R. J. Grant, and M. Morrison. 1998. Effect of soybean hulls, soy lecithin, and soapstock mixtures on ruminal fermentation and milk composition in dairy cows. J. Dairy Sci. 81:462-470.

AOAC International. 2006. Official Methods of Analysis. 18th ed. AOAC International, Arlington, VA.

Armentano, L. E., S. J. Bertics, and G. A. Ducharme. 1997. Response of lactating cows to methionine or methionine plus lysine added to high protein diets based on alfalfa and heated soybeans. J. Dairy Sci. 80:1194-1199.

Bauman, D. E., and J. M. Griinari. 2003. Nutritional regulation of milk fat synthesis. Annu. Rev. Nutr. 23:203-227.

Benefield, B. C., R. A. Patton, M. J. Stevenson, and T. R. Overton. 2009. Evaluation of rumen-protected methionine sources and period length on performance of lactating dairy cows within Latin squares. J. Dairy Sci. 92:4448-4455.

Bertrand, J. A., F. E. Purdue, and T. C. Jenkins. 1998. Effect of ruminally protected amino acids on milk yields and composition of Jersey cows fed whole cottonseed. J. Dairy Sci. 81:2215-2220.

Block, E., E. Evans, C. J. Sniffen, and N. Clark. 2008. Effects of particle size of calcium salts of fatty acids on rates of biohydrogenation and disappearance of essential fatty acids in sacco. J. Dairy Sci. 91(Suppl. 1):332 (Abstr.)

Blum, J. W., R. M. Bruckmaier, and F. Jans. 1999. Rumen-protected methionine fed to dairy cows: Bioavailability and effects on plasma amino acid pattern and plasma metabolite and insulin concentrations. J. Dairy Sci. 82:1991-1998.

Broderick, G. A., and R. E. Muck. 2009. Effect of alfalfa silage storage structure and rumen-protected methionine on production in lactating dairy cows. J. Dairy Sci. 92:1281-1289.

Broderick, G. A., M. J. Stevenson, R. A. Patton, N. E. Lobos, and J. J. Olmos Colmenero. 2008. Effect of supplementing rumen-protected methionine on production and nitrogen excretion in lactating dairy cows. J. Dairy Sci. 91:1092-1102.

Campbell, C. G., E. C. Titgemeyer, and G. St-Jean. 1996. Efficiency of D- vs L-methionine utilization by growing steers. J. Anim. Sci. $74: 2482-2487$.

Campbell, C. G., E. C. Titgemeyer, and G. St-Jean. 1997. Sulfur amino acid utilization by growing steers. J. Anim. Sci. 75:230-238.

Casper, D. P., D. J. Schingoethe, C. M. J. Yang, and C. R. Mueller. 1987. Protected methionine supplementation with extruded blend of soybeans and soybean meal for dairy cows. J. Dairy Sci. 70:321-330.

Chasson, A. L., H. J. Grady, and M. A. Stanley. 1961. Determination of creatinine by means of automatic chemical analysis. Am. J. Clin. Pathol. 35:83-88.

Chen, Z. H., G. A. Broderick, N. D. Luchini, B. K. Sloan, and E. Devillard. 2011. Effect of feeding different sources of rumen-protected methionine on milk production and N-utilization in lactating dairy cows. J. Dairy Sci. 94:1978-1988.
Chikunya, S., G. Demirel, M. Enser, J. D. Wood, R. G. Wilkinson, and L. A. Sinclair. 2004. Biohydrogenation of dietary n-3 PUFA and stability of ingested vitamin $\mathrm{E}$ in the rumen, and their effects on microbial activity in sheep. Br. J. Nutr. 91:539-550.

Clark, J. H. 1975. Lactational responses to postruminal administration of proteins and amino acids. J. Dairy Sci. 58:1178-1197.

Côrtes, C., D. C. da Silva-Kazama, R. Kazama, N. Gagnon, C. Benchaar, G. T. D. Santos, L. M. Zeoula, and H. V. Petit. 2010 Milk composition, milk fatty acid profile, digestion, and ruminal fermentation in dairy cows fed whole flaxseed and calcium salts of flaxseed oil. J. Dairy Sci. 93:3146-3157.

Davidson, S., B. A. Hopkins, J. Odle, C. Brownie, V. Fellner, and L. W. Whitlow. 2008. Supplementing limited methionine diets with rumen-protected methionine, betaine, and choline in early lactation Holstein cows. J. Dairy Sci. 91:1552-1559.

Dawson, R. M. C., D. W. Grimes, and D. B. Lindsay. 1981. On the insensitivity of sheep to the almost complete microbial destruction of dietary choline before alimentary-tract absorption. Biochem. J. 196:499-504.

Doepel, L., D. Pacheco, J. J. Kennelly, M. D. Hanigan, I. F. Lopez, and H. Lapierre. 2004. Milk protein synthesis as a function of amino acid supply. J. Dairy Sci. 87:1279-1297.

Erdman, R. A., and B. K. Sharma. 1991. Effect of dietary rumen-protected choline in lactating dairy cows. J. Dairy Sci. 74:1641-1647.

Firkins, J. L., B. S. Oldick, J. Pantoja, C. Reveneau, L. E. Gilligan, and L. Carver. 2008. Efficacy of liquid feeds varying in concentration and composition of fat, nonprotein nitrogen, and nonfiber carbohydrates for lactating dairy cows. J. Dairy Sci. 91:1969-1984.

Fraser, D. L. 1988. The limiting amino acids for milk production in the dairy cow. PhD Diss. Univ. of Aberdeen, UK.

Illg, D. J., J. L. Sommerfeldt, and D. J. Schingoethe. 1987. Lactational and systemic responses to the supplementation of protected methionine in soybean meal diets. J. Dairy Sci. 70:620-629.

Jenkins, T. C., T. Gimenez, and D. L. Cross. 1989. Influence of phospholipids on ruminal fermentation in vitro and on nutrient digestion and serum lipids in sheep. J. Anim. Sci. 67:529-537.

Jenkins, T. C., and M. A. McGuire. 2006. Major advances in nutrition: Impact on milk composition. J. Dairy Sci. 89:1302-1310.

Kröber, T. F., M. Kreuzer, M. Senn, W. Langhans, and F. Sutter. 2000. Lactational and metabolic effects in cows of lysine and methionine added to a ration deficient according to I.N.R.A. method. Arch. Tierernähr. 53:375-394.

Lapierre, H., G. Holtrop, A. G. Calder, J. Renaud, and G. E. Lobley. 2012. Is D-methionine bioavailable to the dairy cow? J. Dairy Sci. 95:353-362.

Löest, C. A., E. C. Titgemeyer, G. St-Jean, D. C. Van Metre, and J. S. Smith. 2002. Methionine as a methyl group donor in growing cattle. J. Anim. Sci. 80:2197-2206.

Macgregor, C. A., M. R. Knobbe, and A. J. Hugo, inventors. 2005 Method for manufacturing animal feed, method for increasing the rumen bypass capability of an animal feedstuff and animal feed. Grain States Soya Inc., assignee. US Pat. No. 7,297,356.

Macgregor, C. A., L. O. Tedeschi, and T. K. Miller-Webster. 2011. Evaluating the inclusion of Met and Lys to mechanically extracted soybean meal with soy gums on the ruminally-undegraded Met and Lys content. J. Dairy Sci. 94(Suppl. 1):393. (Abstr.)

McDougall, E. I. 1948. Studies on ruminant saliva. 1. The composition and output of sheep's saliva. Biochem. J. 43:99-109.

Merchen, N. R. 1988. Digestion, absorption and excretion in ruminants. Pages 172-201 in The Ruminant Animal Digestive Physiology and Nutrition. D. C. Church, ed. Waveland Press, Long Grove, IL.

Moore, C. E., H. C. Hafliger III, O. B. Mendivil, S. R. Sanders, D. E. Bauman, and L. H. Baumgard. 2004. Increasing amounts of conjugated linoleic acid progressively reduces milk fat synthesis immediately postpartum. J. Dairy Sci. 87:1886-1895.

Moore, S. 1963. On the determination of cystine as cysteic acid. J. Biol. Chem. 238:235-237.

NASS (National Agricultural Statistics Service). 2011. National statistics for milk. Quick stats. Accessed Nov. 3, 2011. 
http://quickstats.nass.usda.gov/results/7414BAB6-1C48-3FBE8018-4589EF552B03?pivot=short_desc.

NRC. 2001. Nutrient Requirements of Dairy Cattle. 7th rev. ed. Natl. Acad. Press, Washington, DC.

Neill, A. R., D. W. Grime, and R. M. C. Dawson. 1978. Conversion of choline methyl groups through trimethylamine into methane in the rumen. Biochem. J. 170:529-535.

Neill, A. R., D. W. Grime, A. M. Snoswell, A. J. Northrop, D. B. Lindsay, and R. M. C. Dawson. 1979. The low availability of dietary choline for the nutrition of the sheep. Biochem. J. 180:559-565.

Ordway, R. S., S. E. Boucher, N. L. Whitehouse, C. G. Schwab, and B. K. Sloan. 2009. Effects of providing two forms of supplemental methionine to periparturient Holstein dairy cows on feed intake and lactational performance. J. Dairy Sci. 92:5154-5166.

Overton, T. R., L. S. Emmert, and J. H. Clark. 1998. Effects of source of carbohydrate and protein and rumen-protected methionine on performance of cows. J. Dairy Sci. 81:221-228.

Overton, T. R., D. W. LaCount, T. M. Cicela, and J. H. Clark. 1996. Evaluation of a ruminally protected methionine product for lactating dairy cows. J. Dairy Sci. 79:631-638.

Paquay, R., R. De Baere, and A. Lousse. 1972. The capacity of the mature cow to lose and recover nitrogen and the significance of protein reserves. Br. J. Nutr. 27:27-37.

Patterson, J. A., and L. Kung. 1988. Metabolism of DL-methionine and methionine analogs by rumen microorganisms. J. Dairy Sci. 71:3292-3301

Patton, R. A. 2010. Effect of rumen-protected methionine on feed intake, milk production, true milk protein concentration, and true milk protein yield, and the factors that influence these effects: A meta-analysis. J. Dairy Sci. 93:2105-2118.

Phipps, R. H., C. K. Reynolds, D. I. Givens, A. K. Jones, P.-A. Geraert, E. Devillard, and R. Bennett. 2008. Short communication: Effects of 2-hydroxy-4-(methylthio) butanoic acid isopropyl ester on milk production and composition of lactating Holstein dairy cows. J. Dairy Sci. 91:4002-4005.

Pinotti, L., A. Baldi, and V. Dell'Orto. 2002. Comparative mammalian choline metabolism with emphasis on the high-yielding dairy cow. Nutr. Res. Rev. 15:315-331.

Russell, J. B., and H. J. Strobel. 1993. Microbial energetics. Pages 165-186 in Quantitative Aspects of Ruminant Digestion and Metabolism. J. M. Forbes and J. France, ed., CAB International, Wallingford, UK.

Samuelson, D. J., S. K. Denise, R. Roffler, R. L. Ax, D. V. Armstrong, and D. F. Romagnolo. 2001. Response of Holstein and Brown Swiss cows fed alfalfa hay-based diets to supplemental methionine at two stages of lactation. J. Dairy Sci. 84:917-928.

Santos, F. A. P., J. E. P. Santos, C. B. Theurer, and J. T. Huber. 1998. Effects of rumen-undegradable protein on dairy cow performance: A 12-year literature review. J. Dairy Sci. 81:3182-3213.

Schingoethe, D. J., F. M. Byers, and G. T. Schelling. 1988a. Nutrient needs during critical periods of the life cycle. Pages 421-447 in The Ruminant Animal Digestive Physiology and Nutrition. D. C. Church, ed. Waveland Press, Long Grove, IL.

Schingoethe, D. J., D. P. Casper, C. Yang, D. J. Illg, J. L. Sommerfeldt, and C. R. Mueller. 1988b. Lactational response to soybean meal, heated soybean meal, and extruded soybeans with ruminally protected methionine. J. Dairy Sci. 71:173-180.

Scholfield, C. R. 1981. Composition of soybean lecithin. J. Am. Oil Chem. Soc. 58:889-892.

Schroeder, G. F., E. C. Titgemeyer, M. S. Awawdeh, J. S. Smith, and D. P. Gnad. 2006. Effects of energy level on methionine utilization by growing steers. J. Anim. Sci. 84:1497-1504.

Schwab, C. G., C. K. Bozak, and N. L. Whitehouse. 1992a. Amino acid limitation and flow to duodenum at four stages of lactation.
1. Sequence of lysine and methionine limitation. J. Dairy Sci 75:3486-3502.

Schwab, C. G., C. K. Bozak, N. L. Whitehouse, and V. M. Olson 1992b. Amino acid limitation and flow to the duodenum at four stages of lactation. 2. Extent of lysine limitation. J. Dairy Sci. 75:3503-3518.

Schwab, C. G., L. D. Satter, and B. Clay. 1976. Response to lactating dairy cows to abomasal infusion of amino acids. J. Dairy Sci $59: 1254-1270$

Shain, D. H., M. H. Sindt, R. J. Grant, T. J. Klopfenstein, and R. A. Stock. 1993. Effect of soybean hull:soy lecithin:soapstock mixture on ruminal digestion and performance on growing beef calves and lactating dairy cattle. J. Anim. Sci. 71:1266-1275.

Sharma, B. K., and R. A. Erdman. 1988. Abomasal infusion of choline and methionine with or without 2-amino-2-methyl-1-propanol for lactating dairy cows. J. Dairy Sci. 71:2406-2411.

Sharma, B. K., and R. A. Erdman. 1989. Effects of dietary and abomasally infused choline on milk production responses of lactating dairy cows. J. Nutr. 119:248-254.

Shingfield, K. J., C. K. Reynolds, G. Hervás, J. M. Griinari, A. S. Grandison, and D. E. Beever. 2006. Examination of the persistency of milk fatty acid composition responses to fish oil and sunflower oil in the diet of dairy cows. J. Dairy Sci. 89:714-732.

St-Pierre, N. R., and J. T. Sylvester. 2005. Effects of 2-hydroxy4-(methylthio) butanoic acid (HMB) and its isopropyl ester on milk production and composition by Holstein cows. J. Dairy Sci 88:2487-2497.

Stern, M. D., T. K. Miller-Webster, W. H. Hoover, M. Ruiz Moreno, and C. A. Macgregor. 2005. Effects of soy gum application to soybean meal on protein degradation by ruminal microbes and intestinal protein digestion. J. Dairy Sci. 88(Suppl. 1):90. (Abstr.)

Tice, E. M., M. L. Eastridge, and J. L. Firkins. 1993. Raw soybean and roasted soybeans of different particle sizes. 1. Digestibility and utilization by lactating cows. J. Dairy Sci. 76:224-235.

Titgemeyer, E. C., and J. E. Shirley. 1997. Effect of processed grain sorghum and expeller soybean meal on performance of lactating cows. J. Dairy Sci. 80:714-721.

Valadares, R. F. D., G. A. Broderick, S. C. Valadares Filho, and M. K. Clayton. 1999. Effect of replacing alfalfa silage with high moisture corn on ruminal protein synthesis estimated from excretion of total purine derivatives. J. Dairy Sci. 82:2686-2696.

Van Soest, P. J., J. B. Robertson, and B. A. Lewis. 1991. Methods for dietary fiber, neutral detergent fiber, nonstarch polysaccharides in relation to animal nutrition. J. Dairy Sci. 74:3583-3597.

Vyas, D., and R. A. Erdman. 2009. Meta-analysis of milk protein yield responses to lysine and methionine supplementation. J. Dairy Sci. 92:5011-5018.

Wallace, R. J. 1994. Amino acid and protein synthesis, turnover, and breakdown by ruminal microorganisms. Pages 71-112 in Principles of Protein Nutrition of Ruminants. J. M. Asplund, ed. CRC Press, Boca Raton, FL

Weiss, W. P., and N. R. St-Pierre. 2009. A method to quantify changes in supply of metabolizable methionine to dairy cows using concentrations of selenium in milk. J. Dairy Sci. 92:2835-2842.

Wildman, E. E., G. M. Jones, P. E. Wagner, R. L. Boman, H. F. Troutt Jr., and T. N. Lesch. 1982. A dairy cow body condition scoring system and its relationship to selected production characteristics. J. Dairy Sci. 65:495-501.

Yang, C.-M. J., D. J. Schingoethe, and D. P. Casper. 1986. Protected methionine and heat-treated soybean meal for high producing dairy cows. J. Dairy Sci. 69:2348-2357. 